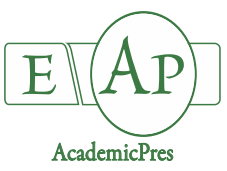

Aly AA et al. (2021)

Notulae Botanicae Horti Agrobotanici Cluj-Napoca

Volume 49, Issue 3, Article number 12396

DOI: $10.15835 /$ nbha 49312396

Research Article

\title{
Physiological variation of irradiated red radish plants and their phylogenic relationship using SCoT and CDDP markers
}

\author{
Amina A. ALY ${ }^{1 *}$, Noha E. ELIWA ${ }^{1}$, Zeyad M. BORIK ${ }^{2}$, \\ Gehan SAFWAT ${ }^{2}$ \\ ${ }^{1}$ Egyptian Atomic Energy Authority, National Center for Radiation Research and Technology, Natural Products Department, Nasr \\ City, P.O.Box., 29,Egypt; aly_amina@yahoo.co.uk (*corresponding author);nohaeliwa@hotmail.com \\ ${ }^{2}$ October University for Modern Science and Art (MSA), Faculty of Biotechnology, \\ Egypt; zeyad.mansour@msa.edu.eg; gehan.safwat@hotmail.co.uk
}

\begin{abstract}
Greenhouse experiment is carried out to explore the outcome of $\gamma$-radiation on physiological and genetic variation in red radish (Raphanus sativus) for two generations. Gamma rays from ${ }^{60} \mathrm{Co}$ were used to penetrate red radish seeds with different dose levels $(0.0,10,20,40$ and $80 \mathrm{~Gy})$. Plants generated from irradiated seeds and from self-pollination of these plants, called M1 and M2 generations, respectively. Some morphological and physiological traits were then determined, and the genetic diversity of both generations was studied using Start Codon Targeted (SCoT) and Conserved DNA-Derived Polymorphism (CDDP) molecular markers. All studied morphological traits (number of leaves/plants, leave height, root diameter, and root weight) were steadily improved by raising irradiation dose rate, reaching a cumulative raise at the irradiation doe level 40 Gy and decreased at dose level 80 Gy. Photosynthetic pigments of red radish plants released a notable increase by increasing gamma rays dose level for chlorophyll (a), chlorophyll (b) and carotenoids for 40 Gy dose rate. Proline content was elevated proportionally to the irradiation dose level, with the greatest increase seen at dose level of 80 Gy. Moreover, phytochemical screening was detected for the both two generations. Fourteen SCoT primers generated a total number of banding patterns of 194 with average 13.86 and the primer SCoT-33 released the highest number banding patterns (21). The percentage mean of polymorphism for all the SCoT primers was $74.66 \%$ and was 66.49 and $63.74 \%$ for M1 and M2 respectively. Furthermore, fifteen CDDP primers generated a total number of banding patterns of 186 and the primer CDDP-5 relieved the highest number of banding patterns (20). The percentage mean of polymorphism for all the CDDP primers was $73.41 \%$ and was 64.38 and $65.91 \%$ for M1 and M2 respectively. It could be concluded that gamma irradiation exhibited an appropriate variation in red radish M1 and M2 which was detected by SCoT and CDDP molecular markers.
\end{abstract}

Keywords: gamma radiation; Raphanus sativus; phytochemical screening; pigments; proline; SCoT; CDDP

Received: 10 Jun 2021. Received in revised form: 25 Jul 2021. Accepted: 09 Aug 2021. Published online: 02 Sep 2021.

From Volume 49, Issue 1, 2021, Notulae Botanicae Horti Agrobotanici Cluj-Napoca journal uses article numbers in place of the traditional method of continuous pagination through the volume. The journal will continue to appear quarterly, as before, with four annual numbers. 


\section{Introduction}

Radish (Raphanus sativus) is a root vegetable that belongs to the family Brassicacea (Cruciferae), and it's cultivated and consumed worldwide and considered to be part of the human diet even though it's not widespread in certain cultures. There are various skin colours for radishes (red, purple, black, yellow, and white to pink), though usually the flesh is white. Moreover, the radish edible roots differ in size, taste, and length around the world (Banihani, 2017). Glucosinolates, anthocyanins, isothiocyanates and phenolic acids, are among the phytochemicals found in radish extracts make radishes have significant health benefits, as it's viewed as protecting vascular smooth muscle cells, being anti-cancer, anti-inflammatory, and antidiabetic (Shin et al., 2015; Manivannan et al., 2019). Induced mutagenesis has been widely used as an effective tool to create desirable variations in traits of some plant species. Plant breeding uses many approaches, among them are induced mutagenesis to create new plant variants. This method is seen as a fast, low-cost, and reproducible technique to speed up the process of generating and viewing crop genotypes with recovered genomics (FAO/IAEA 2017). One of the most widely used physical mutagen is gamma radiation, which has been viewed as a reproducible, reliable, and quick tool to generate morphological and biochemical variations in plant (Jan et al., 2012), hence, gamma radiation has gained an important role in plant breeding and genetic studies intended to progress yield and other advantageous characters in numerous crops (Aly et al., 2019a). Moreover, Gamma radiation can cause variation in the molecular basis of the plants by causing DNA breaks, this can be analyzed by using DNA-based assays to directly identified genotypes (Mengoni et al., 2000). Possibilities in mutation breeding have been increased enormously with the advancements made in the field of genomics and with the developments made in molecular markers techniques. Also, the use of molecular markers in mutation breeding can give us a better insight into the molecular variations that are caused by irradiation with gamma rays, thereby making them ideal for efficient crop breeding, as molecular markers pose as a quick, reproducible, and cost- efficient tool for high throughput screening of mutations in plants (Gaafar et al., 2016). Because of the advancement in molecular systematic approaches, molecular markers appear to be effective methods in assessment of genetic diversity compared to morpho-chemical characterizations (Agarwal et al., 2019). The SCoT and CDDP molecular markers have been developed by Collard and Mackill (2009a and b), those two molecular markers have become one of the most effective gene targeting marker systems in plants. Collard and Mackill (2009a) established SCoT polymorphism as a major marker to identify mutant genotypes as it is relying on the short-conserved regions flanking the ATG start codon of plant genes are needed. Therefore, they can be useful for many applications in plant genotyping and QTL mapping as they are able to screen for polymorphism that might be directly related to gene functions since they based on transcribed regions of the plant genome (Collard and Mackill, 2009c; Tiwari et al., 2016). Marker as SCoT has many advantages over the other commonly used molecular markers for instance AFLP, RAPD and ISSR, as it has been shown to have more reproducibility, stability, as well as producing dependable bands. In addition, it's easy to design, highly polymorphic, and provides ample genetic information of the plant (Satya et al., 2015; Gupta et al., 2019). Such advantages are validated in the latest researches made for the mango genetic diversity, (Zhou et al., 2020), Manilkara (Vanijajiva, 2020), Vitis vinifera (Yue et al., 2019), kiwifruit (Chen et al., 2018). Furthermore, SCoT markers have shown great importance in the identification of genetic variation and characterization of irradiated grape mutant materials (Yue et al., 2019). Otherwise, the CDDP method for generating plants DNA markers based on the information mined for small conserved amino acid sequences present in plant proteins (Mokhtar and Atia, 2019). Such gene-targeted techniques via the use of a gene or promoter in their primers, SCoT and CDDP were created to merge the achievement of marker procedures with modern practical originality, also give greater replication and declaration, by the instantaneous happening of dominant and codominant markers (Abouseadaa et al., 2020). Therefore, in the current study an effort was made to study the genetic diversity using gene targeted (SCoT and CDDP) markers and compare their effectiveness in genetic variation in red radish seeds which were exposed to four levels of $\gamma$-rays doses (10, 20, 40 and $80 \mathrm{~Gy})$ then 
subjected to field trials for two seasons. As well as some physiological and phytochemical characteristics were determined to understand the irradiation effects on plant biochemistry characteristics were concerned.

\section{Materials and Methods}

\section{Gamma irradiation}

Healthy and dry radish seeds (Raphanus sativusL.) which obtained from Gaara and Parteners Company, Bab El-Khalk, Cairo, Egypt. were packed in polypropylene bags and then irradiated by using ${ }^{60} \mathrm{Co}$ as a source for irradiation with gamma doses $(0.0,10,20,40$ and $80 \mathrm{~Gy})$ at a dose rate of $(0.30 \mathrm{~Gy} / \mathrm{Sec})$ using the research irradiator $\left({ }^{60} \mathrm{Co}\right.$ Gamma cell 220 Canada), EAEA, National Center for Radiation Research and Technology (NCRRT), Nasr City, Cairo, Egypt.

The research was conducted at the NCRRT greenhouse during fall seasons of 2019/2020 to investigate the response of red radish to gamma irradiation and the physiological and genetic variation. The M1 radish seeds were planted in the experimental farm, they placed $70 \mathrm{~cm}$ apart and $30 \mathrm{~cm}$ between seeds on both ends of the rows and M1 plants were self-pollinated to produce the M2.

\section{Plant vegetative growth characters}

A random sample size of six for both two generations plants from each treatment was gathered at the horticultural ripeness stage 45 days from sowing. The radish was then deracinated carefully and washed with tap water to remove any residue soil from the deracinated roots. The gathered radish samples were utilized to measure certain vegetative growth parameters, those being, number of leaves, leaves length, root diameter and root weight.

\section{Determination of photosynthetic pigments}

Radish leaves chlorophyll a, b, and carotenoids were measured following a spectrophotometric technique Vernon and Seely (1966). Pigments concentration was evaluated in milligrams per gram of FW.

\section{Proline content}

Concentration of proline was measured according to Bates et al. (1973) method. The findings were calculated in $\mathrm{mg}$ of proline per gram fresh weight.

\section{Preparation of plant extract}

Briefly, $2.0 \mathrm{~g}$ of the fresh root samples were grinded with liquid nitrogen after $25 \mathrm{ml}$ of $80 \%$ ethanol and shaking for $24 \mathrm{~h}$ at room temperature. Whatman filter paper number one was used to filter the extracts then the extraction was repeated twice (Sobhy et al., 2009). The resulting ethanolic extracts volume were adjusted and used for the analysis of the phytochemical screening.

\section{Phytochemical screening analysis for the fresh radish roots}

Various plant compounds were screened using standard analysis for the ethanolic extract. Secondary metabolites like phenols, flavonoids, tannins, coumarins, xanthoproteins, quinones, phlobatannins, saponins, amino acids, alkaloids, carbohydrates, phytosterol, and cholesterol were screened in the extracts for various irradiation dose levels as suggested before by (Trease and Evans 1989; Harborne, 1973; Idu and Igeleke, 2012).

\section{DNA extraction}

Genomic DNA was isolated from the received fresh leaves $(\sim 100 \mathrm{mg})$ sample using a DNeasy Plant Mini Kit (QIAGEN, Santa Clarita, CA), following the producer's procedure. Purified DNA was then quantified using Nanodrop 8000 (Thermo Fisher Scientific Inc.). 


\section{SCoT and CDDP PCR data analysis}

The SCoT PCR amplification analysis was done according to Bhawna et al. (2017), as well as CDDP PCR amplification analysis was done according to Collard and Mackill (2009b). Ten DNA samples corresponding to each treatment from each generation were analyzed for genetic diversity using a set of 14 SCoT primers (Table 1) and 15 CDDP primers. The PCR amplification reaction was performed in reaction mixture included one X Taq polymerase PCR buffer, one $\mathrm{U} T \mathrm{TaKaRa} \mathrm{Taq}^{\mathrm{Tw}} \mathrm{DNA}$ Polymerase (Takara Bio Inc.), $2.0 \mu \mathrm{M}$ of the SCoT and CDDP primer respectively, $2.5 \mathrm{mM} \mathrm{MgCl}_{2}, 0.2 \mu \mathrm{M}$ of each dNTPs and 50-100 ng of DNA gnomic. Nuclease free water was added to maintain a final reaction mixture volume of $25 \mu$. The PCR conditions for SCoT was adjusted with a preliminary denaturation at $94^{\circ} \mathrm{C}$ for 5 minutes, followed by 35 cycles of denaturation at $95^{\circ} \mathrm{C}$ for one minute, annealing for one minute at $50{ }^{\circ} \mathrm{C}$, and extension at $70{ }^{\circ} \mathrm{C}$ for 90 seconds. This was finalized with a final extension at $70^{\circ} \mathrm{C}$ for 7 minutes. Also, the PCR conditions for CDDP at the standard typical PCR cycle was used, which included a 3-minute denaturation stage at $94^{\circ} \mathrm{C}$, followed by 35 cycles of $94^{\circ} \mathrm{C}$ for one minute, $50^{\circ} \mathrm{C}$ for one minute, and $72{ }^{\circ} \mathrm{C}$ for two minutes, with a 5 -minute last extension. The augmented PCR products were then electrophoresed on 1.5 and $1.2 \%$ agarose gel for SCoT and CDDP primers, respectively comprising of ethidium bromide in one X TAE buffer. Amplified PCR products size was measured using a 100 - 1500 bp DNA ladder-plus. The PCR for both primers SCoT and CDDP samples ordered in ascending way (sample-1 to sample-10) during the loading on the agarose gel. Visualization of the PCR products were carried out under UV light and gel images analysis and phylogenetic were achieved using the Python-based tool called PyElph. The base sequences of the DNA primers that generated revealing polymorphic amplicons are listed in Table 1. Used primers sequences that produced polymorphic amplicons are displayed in Tables 4 and 5.

Table 1. SCoT and CDDP primers used in the PCR and their nucleotide sequences

\begin{tabular}{|l|c|c|c|c|}
\hline No. & $\begin{array}{c}\text { SCoT } \\
\text { primers }\end{array}$ & Primer's sequence & $\begin{array}{c}\text { CDDP } \\
\text { primers }\end{array}$ & Primer's sequence \\
\hline 1 & SCoT-31 & CCATGGCTACCACCGCCT & CDDP-1 & TGGCGSAAGTACGGCCAG \\
\hline 2 & SCoT-33 & CCATGGCTACCACCGCAG & CDDP-2 & GTGGTTGTGCTTGCC \\
\hline 3 & SCoT-34 & ACCATGGCTACCACCGCA & CDDP-3 & GCCCTCGTASGTSGT \\
\hline 4 & SCoT-35 & CATGGCTACCACCGGCCC & CDDP-4 & GCASGTGTGCTCGCC \\
\hline 6 & SCoT-36 & GCAACAATGGCTACCACC & CDDP-5 & TGSTGSATGCTCCCG \\
\hline 7 & SCoT -43 & CAATGGCTACCACCGCAG & CDDP-6 & CCGCTCGTGTGSACG \\
\hline 8 & SCoT -52 & ACAATGGCTACCACTGTC & CDDP-7 & GGCAAGGGCTGCCGC \\
\hline 9 & SCoT -69 & ACCATGGCTACCAGCGCA & CDDP-9 & CACTACCGCGGSCTSCG \\
\hline 10 & SCoT -71 & CCATGGCTACCACCGCCG & CDDP-10 & GCSGAGATCCGSGACCC \\
\hline 11 & SCoT -77 & CCATGGCTACCACTACCC & CDDP-11 & TGGCTSGGCACSTTCGA \\
\hline 12 & SCoT-84 & CAACAATGGCTACCACGA & CDDP-12 & AAGGGSAAGCTSCCSAAG \\
\hline 13 & SCoT-86 & CAACAATGGCTACCACGC & CDDP-13 & CACTGGTGGGAGCTSCAC \\
\hline 14 & SCoT -89 & CAACAATGGCTACCACGG & CDDP-14 & AAGCGSCACTGGAAGCC \\
\hline 15 & - & & CDDP-15 & ATGGGCCGSGGCAAGGTGC \\
\hline
\end{tabular}

\section{Statistical analysis}

Three replicates were used in a complete randomized design and the data were displayed as mean \pm standard error. Statistical analysis was carried out using one-way ANOVA, and the differences in means were compared using Duncan's multiple range tests (1955) at $\mathrm{p} \leq 0.05$. 


\section{Molecular analysis}

GelAnalyser3 software was used to analyze the DNA banding patterns produced by each primer. Obvious amplicons were scored as present $(1)$ or absent $(0)$ in a binary matrix for every primer. From this matrix, resolving power $\left(\mathrm{R}_{\mathrm{p}}\right)$ was computed, in accordance with Prevost and Wilkinson (1999), and was estimated following the equation $\mathrm{R}_{\mathrm{p}}=\Sigma \mathrm{I}_{\mathrm{b}}$, where $I_{b}=1-(2 \times|0.5-p|)$, and $\mathrm{p}$ is the genotypes proportion that contains an amplicon. Diversity index (DI) and Polymorphic Information Content (PIC) were determined in accordance with Gorji et al. (2011). Similarity estimates were analyzed using UPGMA (Unweighted pair group method using arithmetic averages). Dice coefficient was then used to calculate the molecular distance (Dissimilarity) (Nei and Li, 1979). A dendrogram was then created based on the similarity data using XLSTAT.7 software.

\section{Results and Discussion}

\section{Growth parameters}

The response of gamma irradiation at different dose levels (0.0, 10, 20, 40 and $80 \mathrm{~Gy})$ on growth parameters in both M1 and M2 generations of radish plant was studied. The obtained results as outlined in Table 2 showed that a remarkable increase of growth parameters by raising exposure dose where the greatest raise was observed at the dose level of $40 \mathrm{~Gy}$ and decreased at dose level $80 \mathrm{~Gy}$. The obtained results as outlined in Table 2 showed that irradiation dose level increased the number of leaves/plants, leaves length, root diameter and root weight by increasing irradiation dose level till the dose level $40 \mathrm{~Gy}(12.87,54.51 \mathrm{~cm} 4.87 \mathrm{~cm}$, and $112.49 \mathrm{~g}$ ), respectively for M1 generation and a similar trend was obtained in M2. Irradiating plants with gamma rays thus show a great effect on the growth parameters of the supposed plant, as it can have stimulatory effects of such morphological aspects and increase yield or height of the plant. This stimulation depends on the dosage of the $\gamma$-rays used and the irradiation rate. Generally, it's seen that irradiated plants with low doses of $\gamma$ rays can enhance growth, cell division, and development in many organisms. Plant growth and development, as well as their adaptation to force challenges, are managed by a number of mechanisms that rely on proper mobilization of growth hormones, cell cycle control, enhancement of relevant enzymes, and adequate nutrient supply as well as the timely appropriate expression of genes that control development phenomena (Salehin et al., 2015). Plants may have their growth traits improved by increasing growth influencing factors and related characteristics. Gamma rays have long been known to improve the growth characteristics of many efficiently significant plants, particularly at low levels (Majeed et al., 2018). Otherwise, Ilyas and Naz (2014) detected enhanced leaf, root, and shoot development in Curcuma longa treated by $60 \mathrm{~Gy}$. Low dose levels of irradiation have been shown to improve plant germination and development, whereas high dose levels result in growth defects, delay in germination, or death of irradiated plants (Majeed et al., 2016; Hong et al., 2017). Growth promoting characteristics and germination of plants subjected to low doses of $\gamma$-irradiation can be due to beneficial mutational effect on genes controlling such characteristics, such as fast DNA repair, and stimulation of hormones and enzymes associated with germination and growth mechanisms (Majeed et al., 2018). Recently, Ahumada-Flores et al. (2021) declared that gamma irradiation induced changes at morphological, physiological, and agronomical levels in wheat. 
Table 2. The mean morphological traits for M1 and M2 generations of red radish (Raphanus sativus) affected by gamma irradiation (Gy)

\begin{tabular}{|l|c|c|c|c|}
\hline \multirow{2}{*}{$\begin{array}{c}\text { Irradiation dose } \\
\text { level (Gy) }\end{array}$} & Leaves number & Leaves length (cm) & Root diameter (cm) & Root weight (g) \\
\cline { 2 - 5 } & \multicolumn{4}{|c|}{ First generation $(\mathrm{M} 1)$} \\
\hline $\mathbf{0}$ & $6.45 \mathrm{C} \pm 0.605$ & $39.37 \mathrm{D} \pm 0.507$ & $2.96 \mathrm{C} \pm 0.191$ & $69.42 \mathrm{D} \pm 1.045$ \\
\hline $\mathbf{1 0}$ & $6.86 \mathrm{C} \pm 0.613$ & $43.737 \mathrm{C} \pm 0.144$ & $3.67 \mathrm{~B} \pm 0.243$ & $78.61 \mathrm{C} \pm 1.239$ \\
\hline 40 & $9.49 \mathrm{~B} \pm 0.487$ & $47.653 \mathrm{~B} \pm 0.461$ & $3.803 \mathrm{~B} \pm 0.026$ & $95.13 \mathrm{~B} \pm 1.365$ \\
\hline $\mathbf{8 0}$ & $12.87 \mathrm{~A} \pm 0.517$ & $54.517 \mathrm{~A} \pm 0.598$ & $4.87 \mathrm{~A} \pm 0.338$ & $112.49 \mathrm{~A} \pm 1.96$ \\
\hline & $6.31 \mathrm{C} \pm 0.22$ & $36.81 \mathrm{E} \pm 0.507$ & $2.597 \mathrm{C} \pm 0.178$ & $73.55 \mathrm{D} \pm 1.274$ \\
\hline $\mathbf{0}$ & $7.04 \mathrm{C} \pm 0.499$ & $42.66 \mathrm{C} \pm 0.662$ & $2.95 \mathrm{~B} \pm 0.219$ & $69.08 \mathrm{D} \pm 1.653$ \\
\hline 10 & $6.5 \mathrm{C} \pm 0.318$ & $45.58 \mathrm{~B} \pm 0.846$ & $3.54 \mathrm{~B} \pm 0.219$ & $78.94 \mathrm{C} \pm 1.323$ \\
\hline $\mathbf{2 0}$ & $9.94 \mathrm{~B} \pm 0.454$ & $47.53 \mathrm{~B} \pm 0.478$ & $3.78 \mathrm{~B} \pm 0.338$ & $95.80 \mathrm{~B} \pm 1.726$ \\
\hline 40 & $13.69 \mathrm{~A} \pm 0.504$ & $52.90 \mathrm{~A} \pm 0.901$ & $5.24 \mathrm{~A} \pm 0.618$ & $116.49 \mathrm{~A} \pm 1.238$ \\
\hline $\mathbf{8 0}$ & $6.783 \mathrm{C} \pm 0.372$ & $37.37 \mathrm{D} \pm 1.013$ & $3.01 \mathrm{~B} \pm 0.143$ & $72.89 \mathrm{D} \pm 1.349$ \\
\hline
\end{tabular}

Data are given as mean \pm SE and various letters within the same column are significantly differences $(\mathrm{p} \leq 0.05)$. M1; First generation, M2; Second generation

\section{Photosynthetic pigments}

The combined graphs in Figure 1 illustrate the effect of gamma irradiation on photosynthetic pigments of radish plants leaves. It is cleared that increasing gamma rays increased the photosynthetic pigment especially at 20 and 40 Gy dose levels. A notable decrease was observed with increasing dose to 80 Gy for both generations. Moreover, an increase in chlorophyll a content was noticed to be higher than the amount of chlorophyll b in un-irradiated and irradiated plants. However, the chlorophyll content was seen to significantly increase with the increase of irradiation dose compared to the control. At the vegetative stage, the results showed that under all gamma irradiation dose levels chlorophyll a was relatively higher than chlorophyll $b$ and the increase in gamma doses increased the difference between them may be due to the more inhibition in chlorophyll b synthesis. The results of the current study concordance with past studies made on the effects of irradiation on pigment content. The current results are in a harmony with Akshatha et al. (2020) who found significantly higher chlorophyll contents have been observed in seedlings treated with radiation compared to the control. This is in concordance with Mohajer et al. (2014), who reported an increase in photosynthetic pigments of the plant Onobrychis viciifolia when exposed to different doses of gamma irradiation compared to un-irradiated plants. According to Majeed et al. (2010), enhanced leaf chlorophyll concentrations and grain yield of Lepidium sativum $L$. at low doses may be the product of improved water and mineral absorption attributable to cell division and enzyme activity enhancement through seed growth. In addition, Zabalza et al. (2006) have suggested that the enhancing effect of radiation on chlorophyll concentration is due to the stabilization of the energetic spot of the enzyme and photosynthetic responses. Marcu et al. (2013) reported a change in pigment concentration and structure in lettuce (Lactuca sastiva) seeds that were irradiated with a gamma radiation at doses ranged from 2 to $70 \mathrm{~Gy}$. This irradiation was detailed to enhance the photosynthetic pigment content at lower doses (2-30 Gy) while at higher doses (70 Gy), the photosynthetic pigments decreased significantly. It was hypothesized that elevated levels of $\gamma$-irradiation have the ability to break the photosynthetic pigments, with the accompanying crippling of the photosynthetic capability. The enhanced levels of chlorophyll $\mathrm{a}$ and $\mathrm{b}$ might be attributed to the enhanced biosynthesis of such pigments in response to the low doses of gamma rays, and/or due to a delay in its degradation process (Aly et al., 2018). Moreover, Saha et al. (2010) assumed that the observed lower levels in chlorophyll b compared to chlorophyll a, in response to higher levels of gamma radiation, might be attributed to deprivation to its biochemical pioneers or due to disruptions in its biosynthesis. Gaafar et al. (2016) have planned that such mutation achieved might have 
established variations in the structure of the plant cells and its metabolites such as dilation of the thylakoid membranes, modification of photosynthesis and accumulation of pigments which would afterward cause a modify of color and textures of the plant.
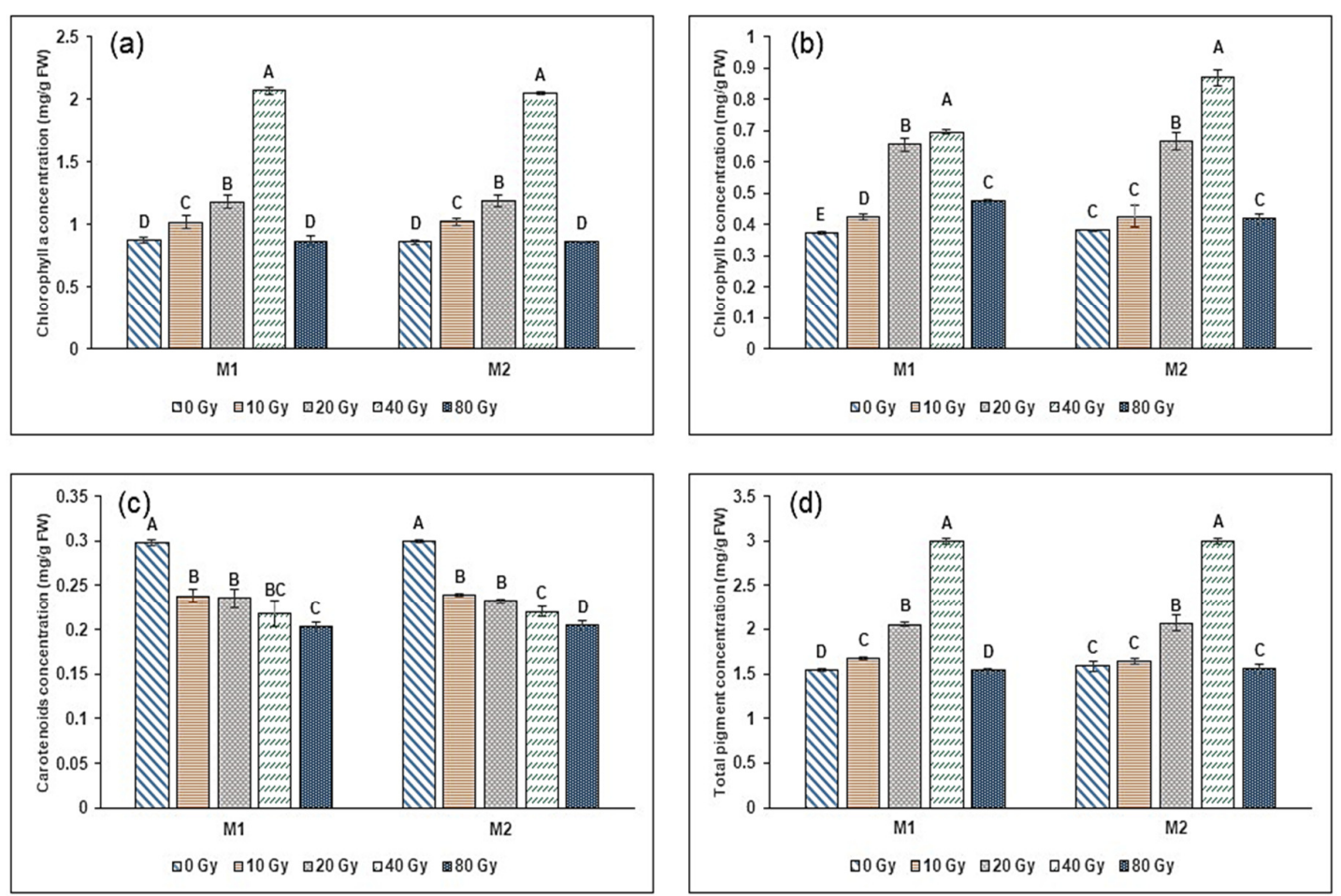

Figure 1. Chlorophyll a (a), chlorophyll b (b), carotenoids (c) and total pigments (d) as affected by gamma irradiation for M1 (First generation) and M2 (Second generation)

Data are given as mean $(n=3)$. Vertical bars show $\pm S E$ and various letters on the bars indicate significantly differences at $\mathrm{p} \leq 0.05$.

\section{Proline content}

Proline content expanded as the irradiation dose rate increased and come to the most extreme increment within the gamma ray level 80 Gy as well as proline content was more pronounced in M2 than M1 (Figure 2). The current study confirms the function of proline as a compatible solute by increasing proline concentration with increasing radiation level, indicating that proline participates in an important role in tolerating the effects of gamma ray. The findings of the current research are in agreements by Akshatha et al. (2013) who reported that proline content increased with increasing irradiation doses in Terminalia arjuna Roxb. Furthermore, Aly et al. (2018 and 2019a) detected that exposure to gamma rays significantly increased proline accumulation in wheat leaves. Radiation stimulates formation of reactive oxygen species (ROS), which is extremely toxic to plant cells. Proline can also be accumulated in a wide variety of organisms as a cytosolic osmoticum, which keeps cells from different environmental stresses with adjusting the osmotic power of the cytosol with that of the vacuole and the exterior atmosphere, in the meantime, as a no enzymatic antioxidant. Proline can scavenge some reactive oxygen species, therefore can stabilizing the structure and role of macromolecules like proteins, lipids and DNA (Wang et al., 2017). The greater proline substances established in plants subjected to extreme and moderate stress might have an important function in plant mending (Khaleghi et al., 2019). 


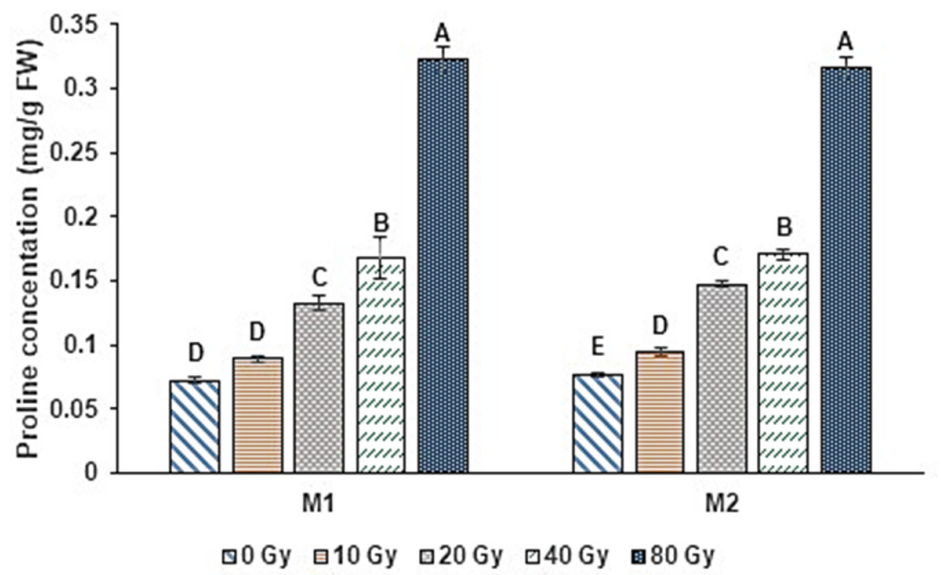

Figure 2. Proline content for M1 and M2 generations of red radish (Rapha sativus) as affected by gamma irradiation (Gy)

Data are given as mean \pm SE $(n=3)$. Various letters on the bars indicate significantly differences at $\mathrm{p}<0.05$.

\section{Phytochemical screening of the ethanolic extract}

Phytochemical screening results of the ethanolic extract of the fresh red radish roots are given in Table 3. The qualitative results were expressed and ranged from presence/positive reaction $(+)$ weakly positive to strong positive reaction $(+++)$ with higher intensity (more concentrated reactions) of phytochemicals. The results showed the presence of phytochemically active compounds such as phenols, flavonoids, tannins, coumarins, xanthoproteins, quinones, phlobatannins, saponins, amino acids, alkaloids, carbohydrates, phytosterol and cholesterol. In the present, study the findings indicated that $\gamma$-rays increased gradually the concentrations of the most phytochemical constituents by increasing irradiation dose level. This is in concordance with Vardhan and Shukla (2017) and El-Beltagi et al. (2013) who detected that low dose of $\gamma$ irradiation may be successful in increasing the development of secondary metabolites. And this is hypothesized to be due to enhance activity of certain biosynthetic enzymes. In the same manner, the effects of various $\gamma$-rays doses (ranging from 5 to $40 \mathrm{~Gy}$ ) on the synthesis of alkaloids and with increasing irradiation doses, the alkaloids content increased as explored by Mohajer et al. (2014). Meanwhile, El-Garhy et al. (2016) proved that there was a connection between the enhancement of flavonoid substances and upregulation of chalcone synthase (CHS) genes in response to $\gamma$-rays. Also, demonstrating that the upgrade in flavonoids substance is went with an increment in CHS expression. Further, the increase in different phenolics and flavonoids can help to mitigate the radiation stress-induced damage. Each phytochemical has a distinct biological action, that may lead to the development of new composites as anti-microbials combat pathogens or to help improve human health (Hassan et al., 2019).

\section{Molecular variation assessment of SCoT and CDDP DNA Markers}

The genetic diversity and phylogenetic relationships of the irradiated M1 and M2 red radish were analyzed using SCoT and CDDP markers. Irradiated Rapha sativus M1 and M2 generations using SCoT marker compared with CDDP marker, fourteen SCoT and fifteen CDDP of the tested primers on red radish sample gave prominent and reproducible amplicons. These primers were selected to perform PCR and obtained banding patterns of these techniques were shown in (Figures 3-5).

The molecular data obtained from banding patterns analysis of SCoT and CDDP (Tables 4 and 5) showed that the SCoT-primers targeted 194 scorable amplicons. Where, a number of amplicons per SCoTprimer ranged from 6 for SCoT- 86 to 21 for SCoT-33, as shown in Table 4. The proportion mean of polymorphism for all the used SCoT-primers was $74.66 \%$ and were 66.49 and $63.74 \%$ for M1 and M2, respectively (Table 4). Also, the molecular size of all targeted ranged from 163 to $2572 \mathrm{bp}$ and the polymorphic percentage ranged from 33.3 to $85.7 \%$ in M1 while in M2 ranged from 16.7 to $82.4 \%$. 
Aly AA et al. (2021). Not Bot Horti Agrobo 49(3):12396

Table 3. Phytochemical screening of M1 and M2 fresh red radish roots as affected by gamma irradiation

\begin{tabular}{|c|c|c|c|c|c|c|c|c|c|c|}
\hline \multirow{3}{*}{$\begin{array}{l}\text { Chemical } \\
\text { constituents }\end{array}$} & \multicolumn{10}{|c|}{ Irradiation dose levels (Gy) } \\
\hline & \multicolumn{5}{|c|}{ M1 } & \multicolumn{5}{|c|}{ M2 } \\
\hline & Control & 10 & 20 & 40 & 80 & Control & 10 & 20 & 40 & 80 \\
\hline Phenol & ++ & ++ & +++ & ++++ & ++++ & ++ & ++ & +++ & ++++ & ++++ \\
\hline Flavonoids & ++ & +++ & +++ & ++++ & ++++ & ++ & +++ & +++ & ++++ & ++++ \\
\hline Tannins & + & + & + & ++ & ++ & + & + & + & ++ & ++ \\
\hline Coumarins & +++ & +++ & +++ & ++++ & ++++ & +++ & +++ & +++ & ++++ & ++++ \\
\hline Xanthoproteins & +++ & +++ & ++++ & ++++ & ++++ & +++ & +++ & ++++ & ++++ & +++ \\
\hline Quinones & +++ & +++ & ++++ & ++++ & +++ & +++ & +++ & ++++ & ++++ & +++ \\
\hline Phlobatannin & +++ & +++ & ++ & ++++ & +++ & +++ & +++ & ++ & ++++ & +++ \\
\hline Saponins & ++ & +++ & +++ & ++++ & ++++ & ++ & +++ & +++ & ++++ & ++++ \\
\hline Amino acids & ++ & +++ & +++ & ++++ & +++ & ++ & +++ & +++ & ++++ & +++ \\
\hline Alkaloids & ++ & ++ & +++ & ++++ & ++++ & ++ & ++ & +++ & ++++ & ++++ \\
\hline Carbohydrates & ++ & ++ & +++ & ++++ & ++++ & ++ & ++ & +++ & ++++ & ++++ \\
\hline Phytosterol & ++ & ++ & ++ & +++ & +++ & ++ & ++ & ++ & +++ & +++ \\
\hline Cholesterol & +++ & +++ & ++ & ++ & ++++ & +++ & +++ & +++ & ++ & ++ \\
\hline
\end{tabular}

+++ Abundant, ++ moderately presence, + present

Table 4. Molecular data estimated from banding patterns of SCoT technique

\begin{tabular}{|c|c|c|c|c|c|c|c|c|c|c|c|c|c|c|c|c|c|c|c|}
\hline \multirow{4}{*}{$\begin{array}{c}\text { Primer } \\
\text { SCoT-31 }\end{array}$} & \multirow{3}{*}{\multicolumn{3}{|c|}{$\begin{array}{c}\text { Molecular size } \\
\text { range bp }\end{array}$}} & \multirow{4}{*}{$\begin{array}{c}\text { All } \\
\text { TA } \\
17\end{array}$} & \multirow{4}{*}{$\begin{array}{r}\text { Pol\% } \\
82.4\end{array}$} & \multirow{4}{*}{$\begin{array}{c}\text { PIC } \\
0.296\end{array}$} & \multirow{4}{*}{$\begin{array}{l}\mathbf{R p}_{\mathbf{p}} \\
7.6\end{array}$} & \multicolumn{6}{|c|}{ M1 } & \multicolumn{6}{|c|}{ M2 } \\
\hline & & & & & & & & \multirow{3}{*}{$\begin{array}{r}\text { TA } \\
14\end{array}$} & \multicolumn{2}{|c|}{$\mathrm{A}+$} & \multicolumn{2}{|c|}{ A- } & \multirow{3}{*}{$\begin{array}{c}\text { Poly } \\
71.4\end{array}$} & \multirow{3}{*}{$\begin{array}{r}\text { TA } \\
16\end{array}$} & \multicolumn{2}{|c|}{ At } & \multicolumn{2}{|c|}{ A- } & \multirow{3}{*}{$\begin{array}{r}\text { Poly } \\
81.3\end{array}$} \\
\hline & & & & & & & & & \multirow{2}{*}{$\begin{array}{c}\mathbf{P A} \\
- \\
2\end{array}$} & \multirow{2}{*}{$\begin{array}{c}\text { UA } \\
- \\
4\end{array}$} & \multirow{2}{*}{$\begin{array}{c}\begin{array}{c}\text { PA } \\
+\end{array} \\
2\end{array}$} & \multirow{2}{*}{$\begin{array}{c}\text { UA } \\
+ \\
2\end{array}$} & & & \multirow{2}{*}{$\begin{array}{c}\text { PA } \\
- \\
4\end{array}$} & \multirow{2}{*}{$\begin{array}{c}\text { UA } \\
- \\
4\end{array}$} & \multirow{2}{*}{$\begin{array}{c}\text { PA } \\
+ \\
4\end{array}$} & \multirow{2}{*}{$\begin{array}{c}\text { UA } \\
+ \\
1\end{array}$} & \\
\hline & 345 & : & 2549 & & & & & & & & & & & & & & & & \\
\hline SCoT-33 & 223 & : & 2572 & 21 & 85.7 & 0.314 & $\begin{array}{c}10 . \\
0\end{array}$ & 17 & 5 & 2 & 4 & 3 & 82.4 & 19 & 6 & 1 & 5 & 3 & 78.9 \\
\hline SCoT-34 & 363 & : & 1994 & 12 & 66.7 & 0.228 & 4.2 & 11 & 1 & 0 & 4 & 1 & 54.5 & 11 & 3 & 0 & 2 & 1 & 54.5 \\
\hline SCoT-35 & 321 & : & 2515 & 17 & 82.4 & 0.251 & 5.8 & 9 & 2 & 0 & 1 & 3 & 66.7 & 17 & 2 & 1 & 3 & 8 & 82.4 \\
\hline SCoT-36 & 163 & : & 1913 & 16 & 87.5 & 0.379 & $\begin{array}{c}10 . \\
2\end{array}$ & 14 & 5 & 0 & 7 & 0 & 85.7 & 16 & 7 & 1 & 4 & 0 & 75.0 \\
\hline SCoT-43 & 244 & : & 2040 & 20 & 80.0 & 0.285 & 8.6 & 18 & 4 & 3 & 4 & 2 & 72.2 & 17 & 4 & 2 & 4 & 3 & 76.5 \\
\hline SCoT-51 & 266 & : & 2045 & 13 & 92.3 & 0.32 & 6.0 & 12 & 3 & 2 & 5 & 0 & 83.3 & 13 & 2 & 2 & 3 & 2 & 69.2 \\
\hline SCoT-52 & 309 & : & 1486 & 12 & 83.3 & 0.297 & 5.2 & 9 & 0 & 2 & 3 & 1 & 66.7 & 12 & 2 & 0 & 6 & 1 & 75.0 \\
\hline SCoT-69 & 219 & : & 1275 & 12 & 66.7 & 0.258 & 5.0 & 12 & 2 & 0 & 4 & 1 & 58.3 & 11 & 2 & 3 & 2 & 0 & 63.6 \\
\hline SCoT-71 & 298 & : & 1739 & 15 & 66.7 & 0.195 & 4.0 & 13 & 3 & 2 & 1 & 2 & 61.5 & 15 & 2 & 0 & 1 & 4 & 46.7 \\
\hline SCoT-77 & 254 & : & 1292 & 10 & 70.0 & 0.25 & 3.8 & 9 & 2 & 1 & 1 & 1 & 55.6 & 10 & 1 & 1 & 5 & 0 & 70.0 \\
\hline SCoT-84 & 170 & : & 960 & 15 & 73.3 & 0.288 & 6.4 & 14 & 2 & 2 & 4 & 1 & 64.3 & 13 & 2 & 3 & 3 & 1 & 69.2 \\
\hline SCoT-86 & 199 & : & 489 & 6 & 33.3 & 0.153 & 1.6 & 6 & 2 & 0 & 0 & 0 & 33.3 & 6 & 0 & 0 & 1 & 0 & 16.7 \\
\hline \multirow[t]{2}{*}{ SCoT-89 } & 464 & : & 1242 & 8 & 75.0 & 0.21 & 2.4 & 8 & 0 & 0 & 4 & 2 & 75.0 & 6 & 2 & 0 & 0 & 0 & 33.3 \\
\hline & \multicolumn{3}{|c|}{ Means } & $\begin{array}{l}13 . \\
86\end{array}$ & $\begin{array}{l}74 . \\
66\end{array}$ & 0.266 & $\begin{array}{l}5 . \\
77\end{array}$ & $\begin{array}{l}11 . \\
86\end{array}$ & 2.36 & 1.29 & 3.14 & 1.36 & 66.49 & $\begin{array}{c}13.0 \\
0\end{array}$ & 2.79 & 1.29 & 3.07 & 1.71 & 63.74 \\
\hline \multirow{2}{*}{$\begin{array}{c}\text { All in } \\
\text { one }\end{array}$} & 170 & : & 2572 & $\begin{array}{c}19 \\
4\end{array}$ & & & & 166 & 33 & 18 & 44 & 19 & 68.67 & 182 & 39 & 18 & 43 & 24 & 68.13 \\
\hline & \multicolumn{3}{|c|}{$\%$} & & & & & $\begin{array}{l}85 . \\
57\end{array}$ & $\begin{array}{l}19 . \\
88\end{array}$ & $\begin{array}{l}10 . \\
84\end{array}$ & $\begin{array}{l}26 . \\
51\end{array}$ & $\begin{array}{l}11 . \\
45\end{array}$ & & $\begin{array}{l}93 . \\
81\end{array}$ & $\begin{array}{l}21 . \\
43\end{array}$ & 9.89 & $\begin{array}{l}23 . \\
63\end{array}$ & $\begin{array}{l}13 . \\
19\end{array}$ & \\
\hline
\end{tabular}

T.A: Total amplicons; A (-): Amplicons, appear in control and absent in one or more of the treatments; PA (-): Polymorphic A (-); UA (-): Unique negative amplicon, absent in one treatment; A (+): Amplicons, absent in control and appear in one or more of the treatments; PA (+): Polymorphic A (+); UA (+): Unique positive amplicon appears in one treatment; Poly. \%: Polymorphism percent. 
Table 5. Molecular data estimated from banding patterns of CCDP technique

\begin{tabular}{|c|c|c|c|c|c|c|c|c|c|c|c|c|c|c|c|c|c|c|c|}
\hline \multirow{4}{*}{$\begin{array}{c}\text { Primer } \\
\text { CDDP-1 }\end{array}$} & \multirow{3}{*}{\multicolumn{3}{|c|}{$\begin{array}{l}\text { Molecular size } \\
\text { range bp }\end{array}$}} & \multirow{4}{*}{$\begin{array}{r}\text { All } \\
\text { TA } \\
12\end{array}$} & \multirow{4}{*}{$\begin{array}{c}\begin{array}{c}\text { Pol } \\
\%\end{array} \\
91.7\end{array}$} & \multirow{4}{*}{$\begin{array}{c}\text { PIC } \\
0.280\end{array}$} & \multirow{4}{*}{$\begin{array}{c}\mathbf{R P}_{\mathbf{P}} \\
4.40\end{array}$} & \multicolumn{6}{|c|}{ M1 } & \multicolumn{6}{|c|}{ M2 } \\
\hline & & & & & & & & \multirow{3}{*}{$\begin{array}{r}\text { TA } \\
10\end{array}$} & \multicolumn{2}{|c|}{ At } & \multicolumn{2}{|c|}{ A- } & \multirow{3}{*}{$\begin{array}{c}\text { Poly } \\
90.0\end{array}$} & \multirow{3}{*}{$\begin{array}{c}\text { TA } \\
12\end{array}$} & \multicolumn{2}{|c|}{ A+ } & \multicolumn{2}{|c|}{ A- } & \multirow{3}{*}{$\begin{array}{r}\text { Poly } \\
75.0\end{array}$} \\
\hline & & & & & & & & & \multirow{2}{*}{$\frac{\text { PA- }}{0}$} & \multirow{2}{*}{$\frac{\text { UA- }}{0}$} & \multirow{2}{*}{$\frac{\text { PA+ }}{4}$} & \multirow{2}{*}{$\begin{array}{c}\text { UA } \\
+ \\
5\end{array}$} & & & \multirow{2}{*}{$\begin{array}{c}\text { PA } \\
- \\
3\end{array}$} & \multirow{2}{*}{$\begin{array}{c}\text { UA } \\
- \\
2\end{array}$} & \multirow{2}{*}{$\begin{array}{c}\text { PA } \\
+ \\
1\end{array}$} & \multirow{2}{*}{$\begin{array}{c}\text { UA } \\
+ \\
3\end{array}$} & \\
\hline & 217 & : & 1484 & & & & & & & & & & & & & & & & \\
\hline CDDP-2 & 242 & $:$ & 1984 & 16 & 68.8 & 0.210 & 4.40 & 14 & 3 & 1 & 2 & 2 & 57.1 & 13 & 4 & 0 & 1 & 2 & 53.8 \\
\hline CDDP-3 & 257 & $:$ & 1939 & 12 & 83.3 & 0.295 & 5.40 & 9 & 2 & 1 & 3 & 1 & 77.8 & 12 & 2 & 1 & 3 & 2 & 66.7 \\
\hline CDDP-4 & 277 & $:$ & 1934 & 15 & 80.0 & 0.256 & 5.200 & 9 & 3 & 0 & 1 & 3 & 77.8 & 15 & 3 & 0 & 4 & 5 & 80.0 \\
\hline CDDP-5 & 154 & $:$ & 1870 & 20 & 75.0 & 0.319 & $\begin{array}{c}10.60 \\
0\end{array}$ & 19 & 5 & 3 & 2 & 3 & 68.4 & 20 & 4 & 1 & 5 & 4 & 70.0 \\
\hline CDDP-6 & 395 & : & 1727 & 12 & 91.7 & 0.313 & 5.60 & 10 & 2 & 1 & 3 & 1 & 70.0 & 12 & 6 & 2 & 1 & 3 & $\begin{array}{c}100 . \\
0\end{array}$ \\
\hline CDDP-7 & 278 & $:$ & 2030 & 16 & 87.5 & 0.366 & 7.200 & 12 & 4 & 1 & 2 & 2 & 75.0 & 15 & 5 & 2 & 5 & 1 & 86.7 \\
\hline CDDP-8 & 153 & : & 1956 & 16 & 81.3 & 0.238 & 4.200 & 13 & 8 & 1 & 0 & 0 & 69.2 & 12 & 4 & 0 & 2 & 3 & 75.0 \\
\hline CDDP-9 & 313 & : & 1476 & 12 & 66.7 & 0.207 & 3.60 & 10 & 2 & 1 & 2 & 0 & 50.0 & 11 & 3 & 2 & 0 & 0 & 45.5 \\
\hline $\begin{array}{c}\text { CDDP- } \\
10\end{array}$ & 312 & $:$ & 1895 & 11 & 72.7 & 0.238 & 3.800 & 11 & 0 & 1 & 7 & 0 & 72.7 & 11 & 0 & 0 & 4 & 1 & 45.5 \\
\hline $\begin{array}{c}\text { CDDP- } \\
11\end{array}$ & 202 & : & 1675 & 14 & 78.6 & 0.270 & 5.400 & 10 & 1 & 0 & 2 & 3 & 60.0 & 13 & 2 & 2 & 1 & 3 & 61.5 \\
\hline $\begin{array}{c}\text { CDDP- } \\
12\end{array}$ & 461 & : & 1978 & 13 & $\begin{array}{c}100 . \\
0\end{array}$ & 0.345 & 6.800 & 10 & 4 & 2 & 1 & 3 & 100.0 & 11 & 5 & 0 & 4 & 1 & 90.9 \\
\hline $\begin{array}{c}\text { CDDP- } \\
13 \\
\end{array}$ & 231 & : & 512 & 7 & 42.9 & 0.146 & 1.400 & 6 & 1 & 0 & 0 & 0 & 16.7 & 7 & 2 & 1 & 0 & 1 & 57.1 \\
\hline $\begin{array}{c}\text { CDDP- } \\
14\end{array}$ & 349 & : & 888 & 7 & 14.3 & 0.026 & 0.200 & 7 & 1 & 0 & 0 & 0 & 14.3 & 7 & 0 & 1 & 0 & 0 & 14.3 \\
\hline \multirow[t]{2}{*}{$\begin{array}{c}\text { CDDP. } \\
15\end{array}$} & 644 & : & 709 & 3 & 66.7 & 0.300 & 1.400 & 3 & 1 & 0 & 1 & 0 & 66.7 & 3 & 1 & 0 & 0 & 1 & 66.7 \\
\hline & \multicolumn{3}{|c|}{ Means } & $\begin{array}{l}12 . \\
40 \\
\end{array}$ & $\begin{array}{l}73 . \\
41\end{array}$ & 0.254 & 4.64 & $\begin{array}{l}10 . \\
20\end{array}$ & 2.47 & 0.80 & 2.00 & 1.53 & 64.38 & 11.60 & 2.93 & $\begin{array}{c}0.9 \\
3\end{array}$ & 2.07 & $\begin{array}{c}2.0 \\
0\end{array}$ & $\begin{array}{l}65 . \\
91\end{array}$ \\
\hline \multirow{2}{*}{ All in one } & 154 & : & 2030 & $\begin{array}{c}18 \\
6\end{array}$ & & & & $\begin{array}{c}15 \\
3\end{array}$ & 37 & 12 & 30 & 23 & 66.67 & 174 & 44 & 14 & 31 & 30 & $\begin{array}{l}68 . \\
39\end{array}$ \\
\hline & \multicolumn{3}{|c|}{$\%$} & & & & & $\begin{array}{l}82 . \\
26\end{array}$ & $\begin{array}{l}24 . \\
18\end{array}$ & 7.84 & $\begin{array}{l}19 . \\
61\end{array}$ & $\begin{array}{l}15 . \\
03\end{array}$ & & 93.55 & $\begin{array}{l}25 . \\
29\end{array}$ & $\begin{array}{l}8 . \\
05\end{array}$ & $\begin{array}{l}17 . \\
82\end{array}$ & $\begin{array}{l}17 . \\
24\end{array}$ & \\
\hline
\end{tabular}

T.A: Total amplicons; A (-): Amplicons, appear in control and absent in one or more of the treatments; PA (-): Polymorphic A (-); UA (-): Unique negative amplicon, absent in one treatment; A (+): Amplicons, absent in control and appear in one or more of the treatments; PA (+): Polymorphic A (+); UA (+): Unique positive amplicon appears in one treatment; Poly. \%: Polymorphism percent 

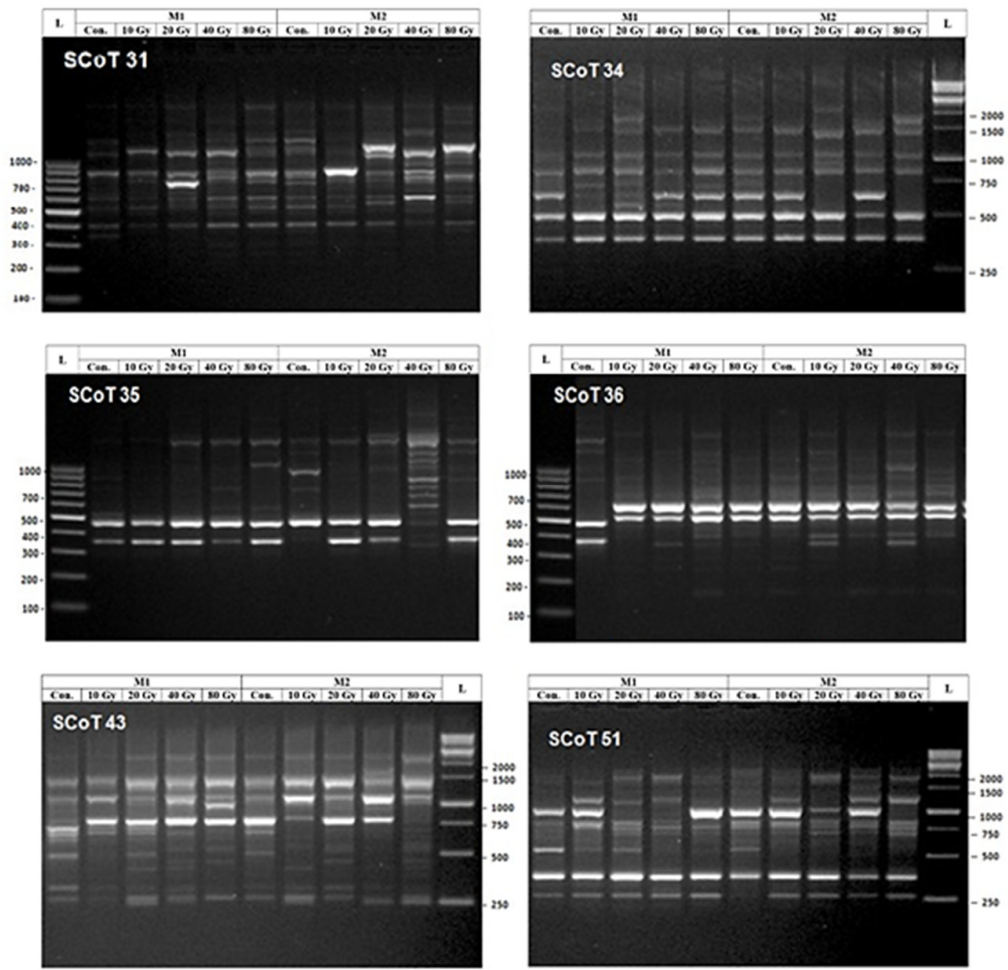

Figure 3. Agarose gel electrophoresis of SCoT amplifications example of the red radish First (M1) and second generations (M2) with 14 primers as affected by gamma irradiation. L, DNA ladder (100-1500 bp) and lanes from 2 to 10 represent the irradiation dose levels for M1 and M2
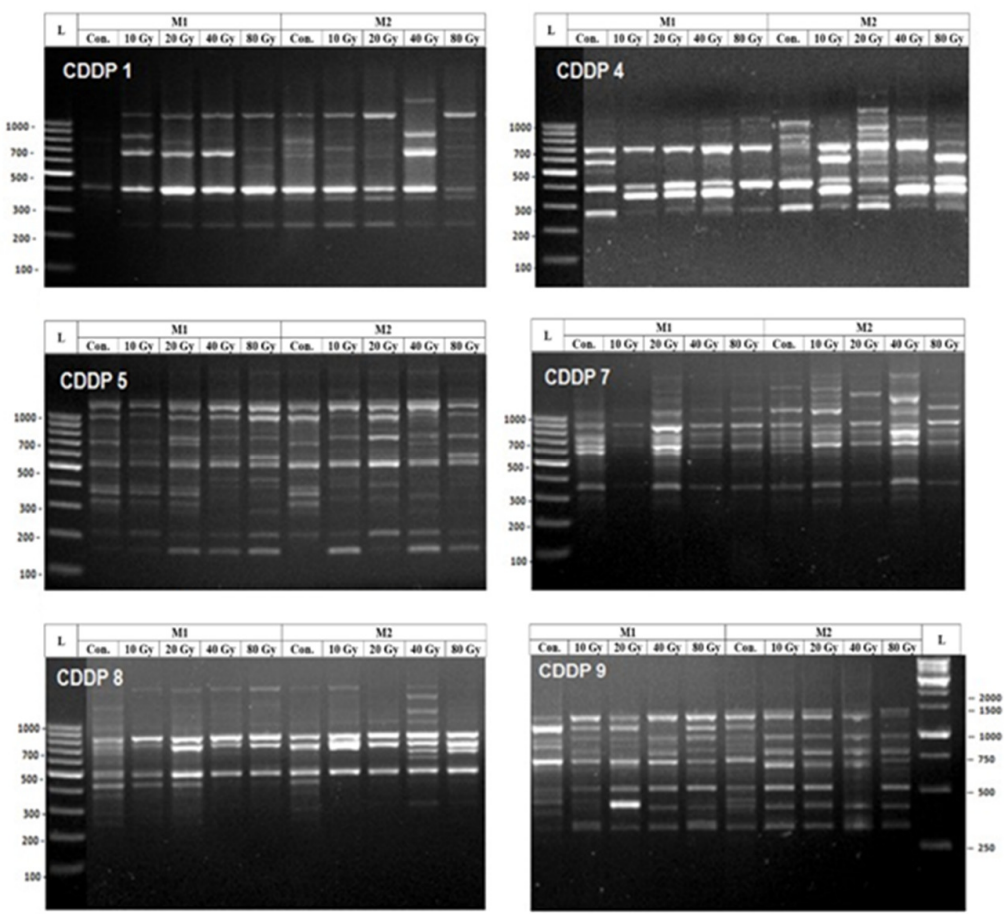

Figure 4. Agarose gel electrophoresis of CDDP amplifications examples of the red radish First (M1) and second generations (M2) with 15 primers as affected by gamma irradiation. L, DNA ladder (100-1500 bp) and lanes from 2 to 10 represent the irradiation dose levels for M1 and M2 
Moreover, the molecular data showed that the CDDP-primers targeted 186 scorable amplicons. Where, a number of amplicons per CDDP-primer ranged from 3 for CDDP-15 to 20 for CDDP-5, as shown in Table 5. The proportion mean of polymorphism for all the used CDDP-primers was $73.41 \%$ and were 64.38 and 65.91\% for M1 and M2, respectively (Table 5). In addition to, the molecular size of all targeted ranged from 153 to $2030 \mathrm{bp}$ and the polymorphic percentage ranged from 14.3 to $100.0 \%$ in both M1 and M2 generations.

The resolving power (Rp) of the SCoT-primers extended from 1.6 for SCoT-86 to 10.2 for SCoT-36, whereas Rp of the CDDP-primers extended from 0.2 for CDDP-14 to 10.60 for CDDP-5.

The polymorphic information content (PIC) is a method to measure the allelic diversity by each primer. The PIC of SCoT-primers ranging from 0.153 for SCoT-86 to 0.379 for SCoT-36. The PIC of CDDPprimers ranging from 0.026 for CDDP- 14 to 0.366 for CDDP-7. Both techniques are proved to be efficient to assess genetic diversity even with different levels of polymorphism as they exhibited 74.66 and 73.41 for SCoT and CDDP, respectively (Table 6). Where, the diversity index (DI) and Rp values for SCoT technique $(0.266$ and 5.77, respectively were higher than that of CDDP technique ( 0.254 and 4.64, respectively). Moreover, they were 0.26 and 5.21, respectively when the two markers combined.

This indicates that the SCoT technique has superior to CDDP technique to distinguish between the studied irradiated red radishes two generations and the assessment for genetic diversity among them.

Cluster analysis was performed to appear the effects of $\gamma$-rays for the molecular levels as well as the relationship between them (Figure 5). The UPGMA dendrograms based on molecular distances (MD) representing the cluster analysis for control and irradiation treatments. The dissimilarity coefficient was 0.20 and 0.25 for $\mathrm{M} 1$ and $\mathrm{M} 2$ respectively, with a total mean of 0.240 when M1 and M2 combined, where the MD is ranged from 0.185 to 0.320 . From these results, it could be concluded that DNA changes occurred in response to irradiation of red radish seeds. The dendrogram, showing 5 main mutant groups, illustrated the effects that take place in plant genetics and diversity when subjected to various $\gamma$-rays doses. It's illustrated that with increasing the doses of radiation, the genetic similarity coefficient of plants that had been irradiated decreased (MD increased), which shows that genetic variation in the irradiated radish increased with the increase of the radiation dose. Nevertheless, the dissimilarity coefficients within M1 and M2 were different at the same irradiation doses. As shown in Table 2, irradiation treatments up to 40 Gy were led to significant economic improvement in several morphological traits that could be linked to the molecular changes.
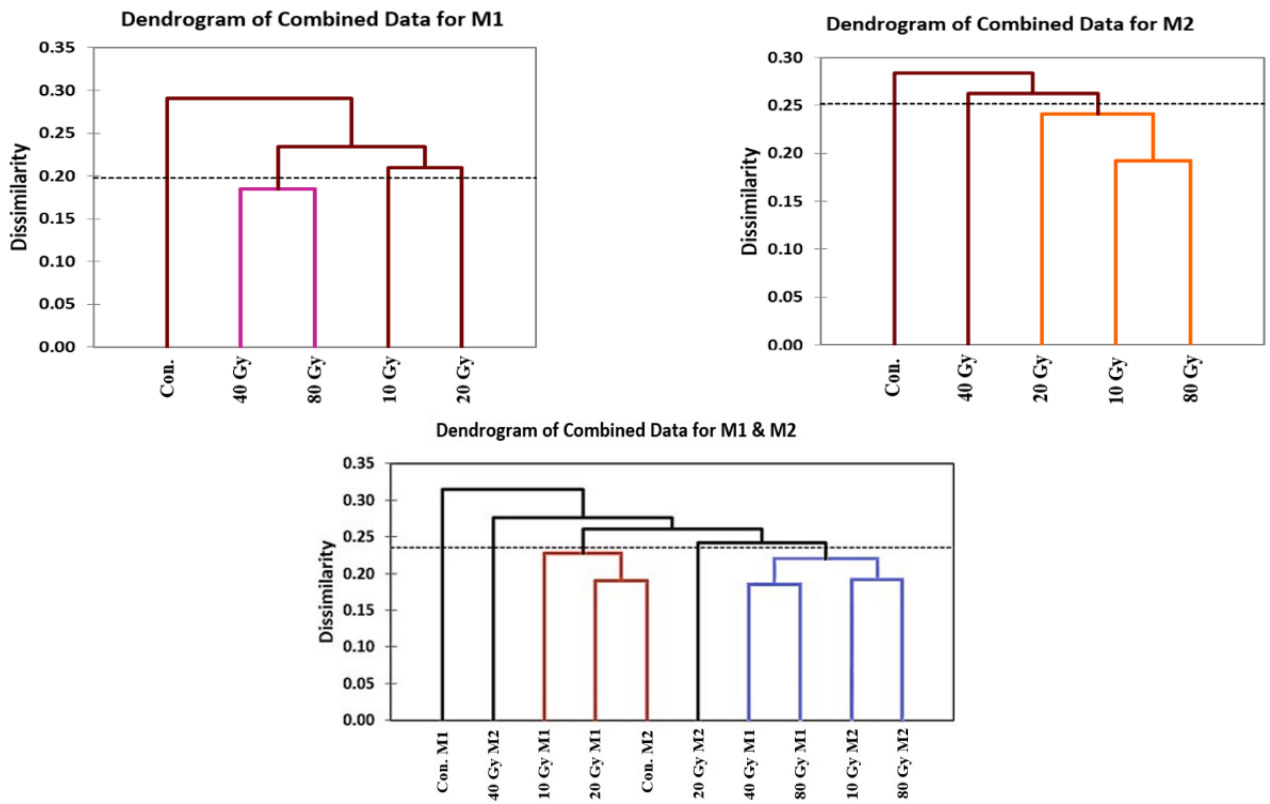

Figure 5. Dendrograms derived by UPGMA method using Dice-dissimilarity coefficient for combined binary data of SCoT and CDDP techniques for M1, M2 and two generations together 
Table 6. Comparison of genetic diversity assessment by SCoT and CDDP technique

\begin{tabular}{|c|c|c|c|c|c|c|c|c|c|c|c|c|c|}
\hline \multirow{2}{*}{$\begin{array}{c}\text { Molecular } \\
\text { marker } \\
\text { technique }\end{array}$} & \multirow{2}{*}{$\begin{array}{c}\text { Molecular } \\
\text { size range } \\
\text { bp }\end{array}$} & \multirow[t]{2}{*}{$\begin{array}{c}\text { Average } \\
\text { of TA }\end{array}$} & \multirow[t]{2}{*}{$\begin{array}{l}\text { Poly. } \\
\%\end{array}$} & \multirow[t]{2}{*}{ DI } & \multirow[t]{2}{*}{$\mathrm{Rp}$} & \multicolumn{3}{|c|}{$\begin{array}{l}\text { UA-in each } \\
\text { generation }\end{array}$} & \multicolumn{3}{|c|}{$\begin{array}{c}\text { UA+ in each } \\
\text { generation }\end{array}$} & \multicolumn{2}{|c|}{$\begin{array}{l}\text { Poly \% in } \\
\text { each } \\
\text { generation }\end{array}$} \\
\hline & & & & & & M1 & M2 & $M$ & M1 & M2 & $\mathrm{M}$ & M1 & M2 \\
\hline SCoT & $163: 2572$ & 13.86 & 74.66 & 0.266 & 5.77 & 18 & 19 & 2.64 & 18 & 24 & 3.00 & 68.67 & 68.13 \\
\hline CCDP & $153: 2030$ & 12.40 & 73.41 & 0.254 & 4.64 & 12 & 23 & 2.33 & 14 & 30 & 2.93 & 66.67 & 68.39 \\
\hline Combined & $153: 2572$ & 13.10 & 74.04 & 0.26 & 5.21 & 30 & 42 & 2.48 & 32 & 54 & 2.97 & 67.67 & 68.26 \\
\hline
\end{tabular}

TA: Total amplicons; Poly. \%: Polymorphism Percent; DI: Diversity Index; Rp: Resolving power; M: mean

The cluster analyses, showed notable variation among control and irradiation treatments for each generation. This variation proved that irradiation treatments applied in this study was succeeded for inducing genetic variations among molecular and phenotypic levels of the both two generations. The distance relation between the irradiation different treatments for M1 and M2 is given in Figure 5.

Results obtained from Table 2 and molecular assessment indicated that, most of irradiation treatments were led to molecular variation with desirable improvement of many studied morphological traits. As no significant decrease in vegetative traits was observed in the current research, this method could be encouraging for breeding efforts, notably for doses $20 \mathrm{~Gy}$ and $40 \mathrm{~Gy}$. It's good to note that this is the first study showcasing the genetic diversity and polygenic relationships of irradiated $M 1$ and $M 2$ red radish by utilizing the SCoT and CDDP molecular markers techniques. The use of SCoT and CDDP markers for studying genetic diversity are reported here for the first time for irradiated red radish. This confirms that the combined data of SCoT and CDDP techniques were suitable for evaluating the genetic relationships among the red radish two generations because they accurate the information about genetic diversity.

The findings of the existing study are in accordance by means of Abd El-Aziz et al. (2017) who indicated that using molecular markers to detect $\gamma$-irradiation mutations associated with desirable traits could be used as marker-assisted selection for improving yield and its components in breeding programs and improvement of okra. In the same concern, Singh and Datta (2009) demonstrated that gamma irradiation encouraged phenotypic changes in wheat, whereas total leaf mass, plant mass and the number of tillers increased 3 times more than control as a result of gamma irradiation. Some past studies made on the effects of $\gamma$-radiation in plants reported that gamma irradiation can cause variations in vegetative characteristics, flowering development, rhizome traits, as well as in maturity in both a negative or positive manner, depending on the applied dose and the radio-sensitivity of the plant being irradiated, where at low doses the plant shows a progression in growth while at high doses of radiation the opposite is seen (Taheri et al., 2014; Ambavane et al., 2015; Aly et al., 2019a). Otherwise, Taheri et al. (2014) observed comparable declines in plant length in the mutant populaces of Curcuma alismatifolia Gagne, and these tendencies are believed to occur as a result of chromosomal aberrations as well as genetic mutations.

It has previously been shown that $\gamma$-irradiation is an important mean of induction mutations in plants (Orazem et al., 2013; Taheri et al., 2014; Aly et al., 2019b). Thus, we can conclude that irradiation with gamma rays was an efficient tool for induction of mutation and reorganization in red radish. These mutants can be efficiently identified using molecular markers such as SCoT and CDDP markers, as seen in the previous results. The SCoT and CDDP markers have been previously used to study genetic diversity in broad series of plant species and have greater benefits in using such markers in the assessment of genetic diversity compared to conventional markers like ISSR (Hamidi et al., 2014; Hajibarat et al., 2015; Saidi et al., 2017). This was confirmed on a study made on potato by Gorji et al. (2011), and in another study made on durum wheat by Etminan et al. (2016). Others have suggested using combination with more than DNA markers for distinctive fingerprinting (Baghizadeha and Dehghan, 2018). Moreover, Wang et al. (2017) confirmed in their study in $S$. davidii that irradiation by gamma-irradiated seeds can produce an adequate number of mutations and the use of molecular markers can be a great tool for identifying such mutations in plants. In the same context, Hajibarat et al. (2015) reported that CDDP and SCoT marker strategies could be used to identify novel genes found by 
plant breeders as a result of in-vitro mutagenesis management. It could be summarized that using these advanced molecular techniques showed changes in non-irradiated and irradiated treatments, based on SCoT and CDDP polymorphism.

\section{Conclusions}

In conclusion, gamma rays were successful in inducing desirable changes in the red radish at the morphological and the molecular levels for both two generations. The SCoT and CDDP molecular markers which could be good methods in generating high number of polymorphism and in detecting genetic diversity in red radish, which might be used for the selection of improved traits induced by gamma irradiation treatments in programs of breeding of red radish. Whereas, the DI and Rp values for SCoT technique (0.266 and 5.77, respectively were higher than that of CDDP technique (0.254 and 4.64, respectively). The maximum number of amplicons (21) was scored by primer SCoT-33 while it was (20) for CDDP-5 primer. Treating red radish with radiation as a mutagenesis resulted in a number of plant morphological and molecular variations in the red radish. The red radish responded to $\gamma$-rays was explored for morphological features, and $\gamma$-rays dose level $40 \mathrm{~Gy}$ was found to be most effective as compared to other treatments. This research offers scientific support for the usefulness for considering $\gamma$-rays as an appropriate method for inducing genetic diversity in red radish and SCoT and CDDP markers were effectively in detecting the genetic diversity for radish as seen from the average percentage of polymorphism produced by each marker.

\section{Authors' Contributions}

A.A.A. - Conceptualization, designed the study, supervision, project administration, curation, editing and reviewed the initial and final draft; N.E.E. - Contributed in the collection of data, prepared the initial draft, the methodology, visualization, review; Z.M.B. - Literature review and contributed in mathematical processing, design, analyzed the data, mathematical processing and genetic analysis; G.S. - Contributed to the conceptualization of ideas, contributed in study design and reviewed the initial draft the manuscripts' review writing and curation, and editing. All authors have read and agreed to the published version of the manuscript. All authors read and approved the final manuscript.

\section{Acknowledgements}

Authors would like to thank the Egyptian Atomic Energy Authority and Faculty of Biotechnology, October University for Modern Science and Art (MSA), Egypt for their support.

\section{Conflict of Interests}

The authors declare that there are no conflicts of interest related to this article. 


\section{References}

Abd El-Aziz MHA, Zaied KA, El-Gendy SEA, Abd ElGawad NA (2017). Evaluation of irradiated okra based on agronomical traits and RAPD markers. Assiut Journal of Agriculture and Science 48:81-96.

Abouseadaa MA, Atia M, Younis IY (2020). Gene-targeted molecular phylogeny, phytochemical profiling, and antioxidant activity of nine species belonging to family Cactaceae. Saudi Journal of Biological Sciences 27(6):1649-1658. https://doi.org/10.1016/j.sjbs.2020.03.007

Agarwal A, Gupta V, Haq SU, Jatav PK, Kothari SL, Kachhwaha S (2019). Assessment of genetic diversity in 29 rose germplasms using SCoT marker. Journal of King Saud University - Science 31(4):780-788. https://doi.org/10.1016/j.jksus.2018.04.022

Ahumada-Flores S, RaydaGómez F, Fannie IselaParra P, Eulogiode la Cruz C, Sarsue Sergiode los T, Villalobosa S (2021). Technical note: Gamma irradiation induces changes of phenotypic and agronomic traits in wheat (Triticum turgidum ssp. durum). Applied Radiation and Isotopes 167:109490 https://doi.org/10.1016/j.apradiso.2020.109490

Akshatha K, Chandrashekar R, Somashekarappa H, Souframanien J (2013). Effect of gamma irradiation on germination, growth, and biochemical parameters of Terminalia arjuna Roxb. Radiation Protection and Environment 36:3844. https://doi.org/10.4103/0972-0464.121826

Akshatha K, Joel Y, Sneha R (2020). Left lower lung collapse in a Patient undergoing endoscopic procedure. Case Report in Anesthesiology 86(70):102. https://doi.org/10.1155/2020/8670102

Aly AA, Eliwa NE, Maraei RW (2019a). Genetic variation based on ISSR in two wheat cultivars after exposing to gamma radiation. ScienceAsia 45(5):436-445. https://doi.org/10.2306/scienceasia1513-1874.2019.45.436

Aly AA, Maraei RW, Aldrussi I (2019b). Changes in peroxidase and polyphenol oxidase activity and transcript levels of related genes in two Egyptian bread wheat cultivars (Triticum aestivum L.) affected by gamma irradiation and salinity stress. Bangladesh Journal of Botany 48:177-186. https://doi.org/10.3329/bjb.v48i1.47482

Aly AA, Maraei RW, Ayadi S (2018). Some biochemical changes in two Egyptian bread wheat cultivars in response to gamma irradiation and salt stress. Bulgarian Journal of Agriculture Science 24:50-59.

Ambavane AR, Sawardekar SV, Sawantdesai SA, Gokhale NB (2015). Studies on mutagenic effectiveness and efficiency of gamma rays and its effect on quantitative traits in finger millet (Eleusine coracana L. Gaertn). Journal of Radiation Research and Applied Sciences 8(1):120-125. http://dx.doi.org /10.1016/j.jrras.2014.12.004

Baghizadeha A, Dehghanb E (2018). Efficacy of SCoT and ISSR markers in the assessment of genetic diversity in some Iranian pistachio (Pistacia vera L.) cultivars. Pistachio and Health Journal 1(1):37-43. http://dx.doi.org/10.22123/PHJ.2017.54299

Banihani SA (2017). Radish (Raphanus sativus) and diabetes. Nutrients 9:1014-1022. https://doi.org/10.3390/nu9091014

Bates LS, Waldren RP, Teare ID (1973). Rapid determination of free proline for water-stress studies. Plant Soil 39:205207. https://doi.org/10.1007/BF00018060

Bhawna M, Abdin Z, Arya L, Verma M (2017). Use of SCoT markers to assess the gene flow and population structure among two different populations of bottle gourd. Plant Gene Journal (9):80-86. https://doi.org/10.1016/j.plgene.2016.09.001

Chen BL, Zhang J, Huang J, Huang C, Zhou Q, Tao W, Tang J (2018). Application of SCoT markers on genetic diversity analysis and variation identification of Actinidia. Journal of Agricultural Biotechnology 26:77-86. https://doi.org/10.3969/j.issn.1674-7968.2018.01.008

Collard BC, Mackill DJ (2009a). Start codon targeted (SCoT) polymorphism: a simple, novel DNA marker technique for generating gene-targeted markers in plants. Plant Molecular Biology Reporter 27(1):86-93. https://doi.org/10.1007/s11105-008-0060-5

Collard BC, Mackill D (2009b). Conserved DNA-derived polymorphism (CDDP): a simple and novel method for generating DNA markers in plants. Plant Molecular Biology Reporter 27(4):558. https://doi.org/10.1007/s11105-009-0118-z

Collard BC, Mackill DS (2009c). Molecular breeding and marker-assisted selection: International Service for the Acquisition of Agro-Biotechnology Applications. Torino, Italy Torino publishing press ltd 43:34-58.

Duncan DB (1955). Multiple range and multiple 'F' tests. Biometrics 11(1):51. http://dx.doi.org/10.2307/3001478 
El-Beltagi HS, Mohamed HI, Mohammed AMA, Zaki LM, Mogazy AM (2013). Physiological and biochemical effects of $\gamma$-irradiation on cowpea plants (Vigna sinensis) under salt stress. Notulae Botanicae Horti Agrobotanici ClujNapoca 41(1):104-114.

EL-Garhy HA, Khattab S, Moustafa MM, Ali RA, Azeiz AZA, Elhalwagi A, ElSherif F (2016). Silybin content and overexpression of chalcone synthase genes in Silybum marianum L. plants under abiotic elicitation. Plant Physiology and Biochemistry 108:191-202. https://doi.org/10.1016/j.plaphy.2016.07.011

Etminan A, Pour-Aboughadareh A, Mohammadi R (2016). Applicability of start codon targeted (SCoT) and inter-simple sequence repeat (ISSR) markers for genetic Equipment 30(6):1075-1081. https://doi.org/10.1080/13102818.2016.1228478

FAO/IAEA (2017). Mutation Breeding. https://www.iaea.org/topics/mutation-breeding

Gaafar RM, Hamouda M, Badr A (2016). Seed coat color, weight and eye pattern inheritance in gamma rays induced cowpea M2-mutant line. Journal of Genetic Engineering and Biotechnology 14:61-68. https://doi.org/10.1016/j.jgeb.2015.12.005.

Gorji AM, Poczai P, Polgar Z, Taller J (2011). Efficiency of arbitrarily amplified dominant markers (SCOT, ISSR and RAPD) for diagnostic fingerprinting in tetraploid potato. American Journal of Potato Research 88:226-237. https://doi.org/10.1007/s12230-011-9187-2

Gupta V, Jatav PK, Haq SU, Verma KS, Kaul VK, Kothari SL, Kachhwaha S (2019). Translation initiation codon (ATG) or SCoT markers-based polymorphism study within and across various Capsicum accessions: insight from their amplification, cross-transferability and genetic diversity. Journal of Genetics 98:1-12. https://doi.org/10.1007/s12041-019-1095-0

Hajibarat Z, Saidi A, Hajibarat Z, Talebi R (2015). Characterization of genetic diversity in chickpea using SSR markers, start codon targeted polymorphism (SCoT) and conserved DNA-derived polymorphism (CDDP). Physiology and Molecular Biology of Plants 21(3):365-373. https://doi.org/10.1007/s12298-015-0306-2

Hamidi MR, Blagica J, Tatjana KP (2014). Toxicological evaluation of the plant products using Brine Shrimp (Artemia salina L.) model. Macedonian Pharmaceutical Bulletin 60(1):9-18. https://doi.org/10.33320/maced.pharm.bull.2014.60.01.002

Harborne JB (1973). Phytochemical methods: A guide to modern techniques of plant analysis. Chapman and Hall Ltd, London.

Hassan A, Ullah H, Israr M (2019). The antioxidant activity and phytochemical analysis of medical plant Veronica biloba. Letters in Applied NanoBi Science 8(4):732-738. https://doi.org/10.25026/jtpc.v5i1.225

Hong MJ, Yoon YH, Kim DS, Kim SH, Kang SY, Kim DY, Kim JB (2017). Phenotypic and molecular responses of wheat (Triticum aestivum L.) to chronic gamma irradiation. Journal of Agricultural Science and Technology 20(1):167-178.

Idu M, Igeleke CL (2012). Antimicrobial activity and phytochemistry of Khaya senegalensis roots. International Journal of Ayurvedic and Herbal Medicine 2:415-422.

Ilyas S, Naz S (2014). Effect of gamma irradiation on morphological characteristics and isolation of curcuminoids and oleoresins of Curcuma longa L. Journal of Animal and Plant Sciences 24(5):1396-1404.

Jan S, Parween T, Siddiqi TO, Mahmooduzzafar (2012). Effect of gamma radiation on morphological, biochemical and physiological aspects of plants and plant products. Environmental Reviews 20:17e39. https://doi.org/10.1139/a11-021

Khaleghi M, Khorrami S, Ravan H (2019). Identification of Bacillus thuringiensis bacterial strain isolated from the mine soil as a robust agent in the biosynthesis of silver nanoparticles with strong antibacterial and anti-biofilm $\begin{array}{lllll}\text { activities. Biocatalysis and Aricultural Biotechnology } & \text { 18:1047. }\end{array}$ https://doi.org/10.1016/j.bcab.2019.101047

Majeed A, Muhammad Z, Ullah R, Ali H (2018). Gamma irradiation effect on germination and general growth characteristics of plants-a review. Pakistan Journal of Botany 50(6):2449-2453.

Majeed A, Muhammad Z, Ullah R (2016). Growth and yield response of field pea (Pisum sativum L.) to gamma irradiation stress. Plant Breeding and Seed Science 74(2):27-35. http://ojs.ihar.edu.pl/index.php/pbss/article/view/219

Majeed A, Khan A, Habib A, Zahir M (2010). Gamma irradiation effects on some growth parameters of Lepidium sativum L. ARPN Journal of Agricultural and Biological Science 5(1):39-42.

Manivannan A, Kim JH, Kim DS, Lee ES, Lee HE (2019). Deciphering the nutraceutical potential of Raphanus sativus A comprehensive overview. Nutrients 11(2):402-416. https://doi.org/10.3390/ nu11020402. 
Marcu D, Cristea V, Daraban L (2013). Dose-dependent effects of gamma radiation on lettuce (Lactuca sativa var. capitata) seedlings. International Journal of Radiation Biology 89(3):219-223. https://doi.org/10.3109/09553002.2013.734946

Mengoni A, Gori A, Bazzicalupo M (2000). Use of RAPD and microsatellite SSR variation to assess genetic relationships among populations of tetraploid alfalfa Medicago sativa. Plant Breeding 119(4):311-317. https://doi.org/10.1046/j.1439-0523.2000.00501.x

Mohajer S, Taha R, Lay MM, Esmaeili AK, Khalili M. (2014). Stimulatory effects of gamma irradiation on phytochemical properties, mitotic behaviour, and nutritional composition of sainfoin (Onobrychis viciifolia Scop.). The Scientific World Journal 85:4093- 4099.

Mokhtar M, Atia SS (2019). Rome: an integrated database and pipelines for exploring microsatellites in all organisms. Nucleic Acids Research 47:D245-D252. https://doi.org/10.1093/nar/gky998

Nei M, Li WH (1979). Mathematical model for studing genetic variation in terms of restriction endonucleases. Proceedings of the National Academy of Sciences USA 76:5269- 5273.

Orazem P, Stajner N, Bohanec B (2013). Effect of X-ray irradiation on olive shoot culture evaluated by morphological measurements, nuclear DNA content and SSR and AFLP markers. Trees 27(6):1587-1595. https://doi.org/10.1007/s00468-013-0906-9

Prevost A, Wilkinson MJ (1999). A new system for comparing PCR primers applied to ISSR fingerprinting of potato cultivars. Theoretical and Applied Genetics 98:107-112.

Saha S, Moorthi S, Pan HL, Wu XR, Wang JD, Nadiga S, ... Goldberg M (2010). The NCEP climate forecast system reanalysis. Bulletin of American Meteorological Society 91:1015-1057. http://dx.doi.org/10.1175/2010BAMS3001.1

Saidi M, Mergby D, Brini F (2017). Identification and expression analysis of the NAC transcription factor family in durum wheat (Triticum turgidum L. ssp. durum). Plant Physiology and Biochemistry 112:117-128. https://doi.org/10.1016/j.plaphy.2016.12.028

Salehin M, Bagchi R, Estelle M (2015). SCFTIR1/AFB-based auxin perception: mechanism and role in plant growth and development. The Plant Cell 27:9-19. https://doi.org/10.1105/tpc.114.133744

Satya P, Karan M, Jana S, Mitra S, Sharma A, Karmakar PG, Ray DP (2015). Start codon targeted (SCoT) polymorphism reveals genetic diversity in wild and domesticated populations of ramie (Boehmeria nivea L. Gaudich.), a premium textile fiber producing species. Meta Gene 3:62-70. https://doi.org/10.1016/j.mgene.2015.01.003

Shin T, Ahn M, Kim GO, Park SU (2015). Biological activity of various radish species. Oriental Pharmacy and Experimental Medicine 15(2):105-111. https://doi.org/10.1007/s13596-015-0183-9

Singh B, Datta PS (2009). Gamma irradiation to improve plant vigour, grain development, and yield attributes of wheat. Radiation Physics and Chemistry 79(2):139-143. https://doi.org/10.1016/j.radphyschem.2009.05.025

Sobhy M, Abdalla M, Ammar S (2009). Total phenolic contents and antioxidant activity of corn tassel extracts. Food Chemistry 112:595-598. https://doi.org/10.1016/j.foodchem.2008.06.014

Taheri S, Abdullah T, Ahmad Z, Abdullah NAP (2014). Effect of acute gamma irradiation on Curcuma alismatifolia varieties and detection of DNA polymorphism through SSR marker. BioMed Research International 631813. https://doi.org/10.1155/2014/631813

Tiwari G, Singh R, Singh N, Choudhury DR, Paliwal R, Kumar A, Gupta V (2016). Study of arbitrarily amplified (RAPD and ISSR) and gene targeted (SCoT and CBDP) markers for genetic diversity and population structure in Kalmegh [Andrographis paniculata (Burm. f.) Nees]. Industrial Crops and Products 86:1-1. https://doi.org/10.1016/j.indcrop.2016.03.031

Trease G, Evans W (1989). Text Book of Pharmocognosy, 14th edn. (Alden Press, Oxford, 1989), pp 213.

Vanijajiva O (2020). Start codon targeted (SCoT) polymorphism reveals genetic diversity of Manilkara in Thailand. Biodiversitas 21(2):666-673. https://doi.org/10.13057/biodiv/d210232

Vardhan PV, Shukla LI (2017). Gamma irradiation medicinally important plants and the enhancement of secondary metabolite production. International Journal of Radiation Biology 93(9):967-979. https://doi.org/10.1080/09553002.2017.1344788

Vernon LP, Seely GR (1966). The Chlorophylls: Physical, Chemical and Biological Properties, 1st edn. Academic Press, New York.

Wang P, Zhang Y, Zhao L, Mo B, Luo T (2017). Effect of gamma rays on Sophora davidii and detection of DNA polymorphism through ISSR marker. BioMed Research International 8576404. https://doi.org/10.1155/2017 18576404 
Yue Q,Zhang C, Wang Q, Wang W, Wang J, Wu Y (2019). Analysis on genetic diversity of 51 grape germplasm resources. Ciência Rural 49 (11):e20190247. https://doi.org/10.1590/0103-8478cr20190247

Zabalza A, Gaston S, Ribas-Carbo M, Orcaray L, Igal M, Royuela M (2006). Nitrogen assimilation studies using $15 \mathrm{~N}$ in soybean plants treated with imazethapyr, an inhibitor of branched-chain amino acid biosynthesis. Journal of Agricultural and Food Chemistry 54:8818-8823. https://doi.org /10.1021/jf0618224

Zhou L, He XH, Yu HX, Chen MY, Fan Y, Zhang XJ, ... Luo C (2020). Evaluation of the genetic diversity of mango (Mangifera indica L.) seedling germplasm resources and their potential parents with start codon targeted (SCoT) markers. Genetic Resources and Crop Evolution 67:41-58. https://doi.org/10.1007/s10722-01900865-8

OPEN ACCESS

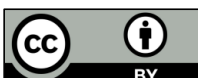

The journal offers free, immediate, and unrestricted access to peer-reviewed research and scholarly work. Users are allowed to read, download, copy, distribute, print, search, or link to the full texts of the articles, or use them for any other lawful purpose, without asking prior permission from the publisher or the author.

License - Articles published in Notulae Botanicae Horti Agrobotanici Cluj-Napoca are Open-Access, distributed under the terms and conditions of the Creative Commons Attribution (CC BY 4.0) License. (C) Articles by the authors; UASVM, Cluj-Napoca, Romania. The journal allows the author(s) to hold the copyright/to retain publishing rights without restriction. 